\title{
OR. 33.2
}

\section{GA-A14860}

UC-77

\section{DESIGN EVALUATION: PNEUMATIC TRANSPORT AND CLASSIFICATION}

\author{
by \\ J. M. MENAIR
}

Prepared under

Contract DE-AT03-76SF71053

for the San Francisco Operations Office

Department of Energy

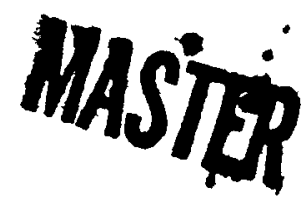

DATE PREPARED: APRIL 1978

DATE PUBLISHED: OCTOBER 1979 


\section{NOTICE}

This report was prepared as an account of work sponsored by the United States Government. Neither the United States nor the Department of Energy, nor any of their employees, nor any of their contractors, subcontractors, or their employees, makes any warranty, express or implied, or assumes any legal liability or responsibility for the accuracy, completeness or usefulness of any information, apparatus, product or process disclosed, or represents that its use would not infringe privately owned rights.

Printed in the United States of America Available from

National Technical Information Service

U.S. Department of Commerce 5285 Port Royal Road

Springfield, Virginia 22161

Price: Printed Copy $\$ 4.50$; Microfiche $\$ 3.00$ 


\section{DISCLAIMER}

This report was prepared as an account of work sponsored by an agency of the United States Government. Neither the United States Government nor any agency Thereof, nor any of their employees, makes any warranty, express or implied, or assumes any legal liability or responsibility for the accuracy, completeness, or usefulness of any information, apparatus, product, or process disclosed, or represents that its use would not infringe privately owned rights. Reference herein to any specific commercial product, process, or service by trade name, trademark, manufacturer, or otherwise does not necessarily constitute or imply its endorsement, recommendation, or favoring by the United States Government or any agency thereof. The views and opinions of authors expressed herein do not necessarily state or reflect those of the United States Government or any agency thereof. 


\section{DISCLAIMER}

Portions of this document may be illegible in electronic image products. Images are produced from the best available original document. 
GA-A14860

UC-77

\title{
DESIGN EVALUATION: PNEUMATIC TRANSPORT AND CLASSIFICATION
}

\author{
by \\ J. M. McNAIR
}

Prepared under

Contract DE-AT03-76SF71053

for the San Francisco Operations Office

Department of Energy

GENERAL ATOMIC PROJECT 3261

DATE PREPARED: APRIL 1978

DATE PUBLISHED: OCTOBER 1979

\section{GENERAL ATOMIC COMPANY}




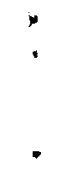

$-$ 


\section{ABSTRACT}

This report describes the evaluation of selected design features of the cold engineering scale pneumatic transport and classification subsystems used in the development of the head-end equipment for HTGR fuel reprocessing. The report identifies areas that require further design effort and evaluation of alternatives prior to the design of the HTGR reference recycle facility (HRRF). Seven areas in the transport subsystem and three in the classification subsystem were selected for evaluation. Seventeen specific recommendations are presented for further design effort. 
TABLE OF CONTENTS

ABSTRACT . . . . . . . . . . . . . . . . . . . . $i$ ii

1. SUMMARY . . . . . . . . . . . . . . . . . . . 1

2. INTRODUCTION . . . . . . . . . . . . . . . . . 3

3. EVAlUATION . . . . . . . . . . . . . . . . . . . . 5

3.1. Conveying Lines... . . . . . . . . . . . . . 5

3.1.1. Introduction ................ . 5

3.1.2. Couplings ................. 5

3.1.3. Methods of Testing the Occurrence and Location of Flow Blockages in the Conveying Lines . . . 8

3.1.4. Methods of Removing Flow Blockages ....... 14

3.1.5. Method of Detection and Prevention or Repair of Bend Erosion... . . . . . . . . 18

3.2. In-Bunker Filters . . . . . . . . . . . . . 19

3.2.1. Introduction .............. 19

3.2.2. Filter Blowback Configuration . . . . . . . 19

3.3. Leve1 Sensors . . . . . . . . . . . . . . . 20

3.3.1. Introduction . . . . . . . . . . . 20

3.3.2. Level Sensor Requirements . . . . . . . . . 20

3.4. Feeders . . . . . . . . . . . . . . . 23

3.4.1. Introduction ... . . . . . . . . . . 23

3.4.2. Crusher Discharge .............. 23

3.4.3. Secondary Burner Product Bunker to Transport System . . . . . . . . . . . . 24

3.4.4. Primary Burner Feeder . . . . . . . . . 25

3.5. Weight Cells . . . . . . . . . . . . . 26

3.5.1. Introduction .. . . . . . . . . . 26

3.5.2. Bunker Support Structure . . . . . . . . 27

3.5.3. Bunker Connections . . . . . . . . . . . 27

3.6. Samplers . . . . . . . . . . . . . . 28 


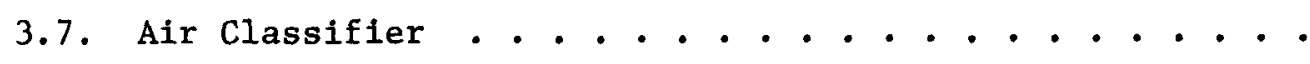

3.7.1. Introduction .............

3.7.2. Combination of the Cyclone, Filter, and Possibly the Fissile Bunkers . . . . . . . . 30

3.7.3. Shape Separation of Classifier Overflow .... 34

3.7.4. Differential Leaching of Classifier Underflow . . 34

ACKNOWLEDGMENTS . . . . . . . . . . . . . . . . 35

REFERENCES ......................... 36

\section{FIGURES}

1. Integral pipe coupling and pipe support ......... 7

2. Bellows coupling ................. 9

3. Sonic plug detector ................ 11

4. Acoustic plug detector ................. 12

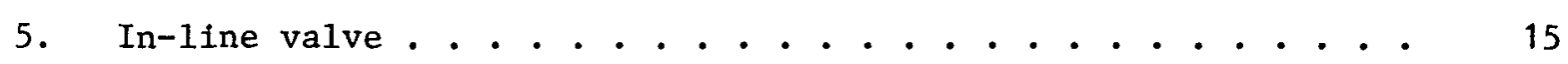

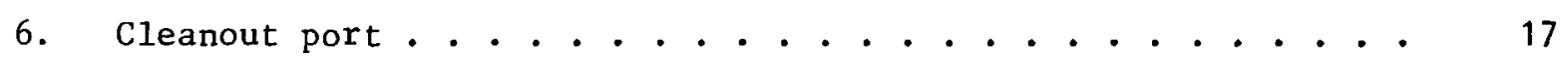

7. Alternate assembly method for filter blowback ........ 21

8. Schematic diagram of fuel particle classifier . . . . . . 31

9. Schematic diagram of fuel particle classifier with cyclone and filter combined.................... 32

10. Schematic diagram of fuel particle classifier with cyclone, filter, and burner combined ............ 33 


\section{SUMMARY}

The design of the pneumatic transport and classification systems in the HTGR fuel reprocessing cold engineering pilot plant has been evaluated. Areas that require further design effort prior to the design of the HRRF have been identified. The resultant recommendations are:

1. Establish and implement a test program to evaluate remote coupling devices for the transport system conveying lines.

2. Develop a reliable solids flow rate sensor.

3. Develop methods of locating blockages in transport lines.

4. Develop methods of remotely unplugging blocked transport lines.

5. Design transport lines so that they can be disassembled if a11 other methods of removing a blockage fail.

6. Implement an experimental program to determine the wear rates of transport piping.

7. Change the design of the in-bunker filter blowback system to one not requiring precise alignment of the air jet and venturi.

8. Develop reliable level sensors for all storage bunkers, with emphasis on a sensor that will work with all materials encountered in dry head-end processing.

9. Install a rotary feed valve on the UNIFRAME discharge, and monitor particle breakage results. 
10. Install and test a test rotary feed valve on the secondary burner product hopper discharge.

11. Install a 4-in. rotary valve and a surge hopper on the primary burner feed bunker.

12. Keep the present rigid bunker support systems and concentrate on aligning the tie bars to prevent bunker rotation.

13. Investigate methods of connecting bunkers to feed lines with couplings that will neither trap material nor transmit forces.

14. Define the requirements of the sampling system.

15. Define the requirements of the pneumatic classifier overflow stream and, if possible, combine the cyclone and the filter bunker.

16. Study the feastbility of using shape separators to separate broken fertile particles from the classifier overflow stream.

17. Study the feasibility of using differential leaching to minimize the consequences of uranium crossover to the classifier thoria product stream. 


\section{INTRODUCTION}

The pneumatic transport system in the cold engineering scale head-end pilot plant (Ref. 1) consists of vacuum pneumatic transport subsystems connecting the various unit operations in the reprocessing scheme. Fuel elements are reduced to a size compatible with the primary burner by the UNIFRAME crusher. The crushed material is conveyed to the crusher product bunker and then to the feed bunker of the primary burner. The graphite and outer carbon coatings of the fuel particles are burned off and the product is conveyed to the primary burner product bunker.

The product is transferred to the classifier feed bunker and fed into a moving air stream within the pneumatic classification column. The lighter, (fissile) particles are carried out of the top of the classifier, and the heavier (fertile) particles fall out of the bottom. The fertile particles are transported to a product bunker and are ready for dissolution and solvent extraction. The fissile particles are conveyed to a particle crusher, where the silicon carbide coatings are fractured. These crushed particles are then transported to the secondary burner, where the inner carbon coatings and metal carbides are burned. Product from the burner is transported to the secondary burner product bunker and is ready for dissolution and solvent extraction.

The pneumatic classification system is included in this design evaluation since many of its features are simflar to those of the pneumatic transport system. The present design of the transport system is described in Ref. 2.

The areas considered in this design evaluation were selected based on discussions with cognizant personnel (see acknowledgments) about problems experienced or expected in the systems evaluated. As a result of these 
discussions, six areas in the transport system and three in the classification system were identified as needing further evaluation. Several features of the transport system are not addressed in the report because the present configuration is believed to be unique to the cold engineering pilot plant; the configurations needed in the HRRF will be governed by other studies (e.g., criticality, heat dissipation).

The areas selected for evaluation are:

\section{Pneumatic Transport}

1. Conveying lines.

2. In-bunker filters.

3. Leve1 sensors.

4. Feeders.

5. Weigh cells.

6. Samplers.

\section{Pneumatic Classification}

1. Combining overflow bunker, filter, and cyclone.

2. Shape separation of the classifier overflow.

3. Differential leaching of the classifier underflow. 


\section{EVALUATION}

3. 1. CONVEYING LINES

3.1.1. Introduction

Four design features of the pneumatic conveying lines were identified as requiring further evaluation. These are:

1. Type of line couplings used.

2. Method of detecting the occurrence and location of flow blockages in the conveying lines.

3. Method of removing the flow blockages for resumption of transport.

4. Method of detection and prevention or repair of bend erosion.

The effect of conveying line geometry on material transport was also identified as needing further evaluation and is presently being studied; it will therefore be discussed in future reports.

\subsubsection{Couplings}

3.1.2.1. Function. The transport system piping should have remotely operated couplers to allow disassembly of the transport lines for reasons outlined below: 
1. Access to other equipment for maintenance.

2. Removal of solids transport equipment for maintenance.

3. Repair or replacement of damaged or worn transport piping.

4. Removal of flow blockages that resist all other unplugging methods.

3.1.2.2. Design Requirements. The couplings should be easy to disassemble by standard remote methods, should maintain an airtight seal in a radiation and elevated-temperature environment, and should minimize material spills during disassembly.

3.1.2.3. Operating Experience. The following methods of coupling transport lines have been used in the cold engineering pilot plant:

1. $\operatorname{Tri}_{-\mathrm{Clamp}}{ }^{\circledR}$ (Ladish Co.).

2. GC Fast Clamp (G\&H Products).

3. Marman MG Couplings (Aeroquip Corp.).

However, based on pllot plant experience, none of these clamping devices will perform satisfactorily with remote operation without some modification.

\subsubsection{Alternatives}

1. Pipe Coupling and Pipe Support Combination (Fig. 1). This type of coupling has the advantage of combining both pipe support and coupling in one mechanism. It is easy to actuate remotely and requires only rough manual alignment, as the guides provide the final alignment. The disadvantages are that this configuration lends itself more to horizontal than vertical applications and the stand continues to occupy floor space after the transport piping has been removed. 


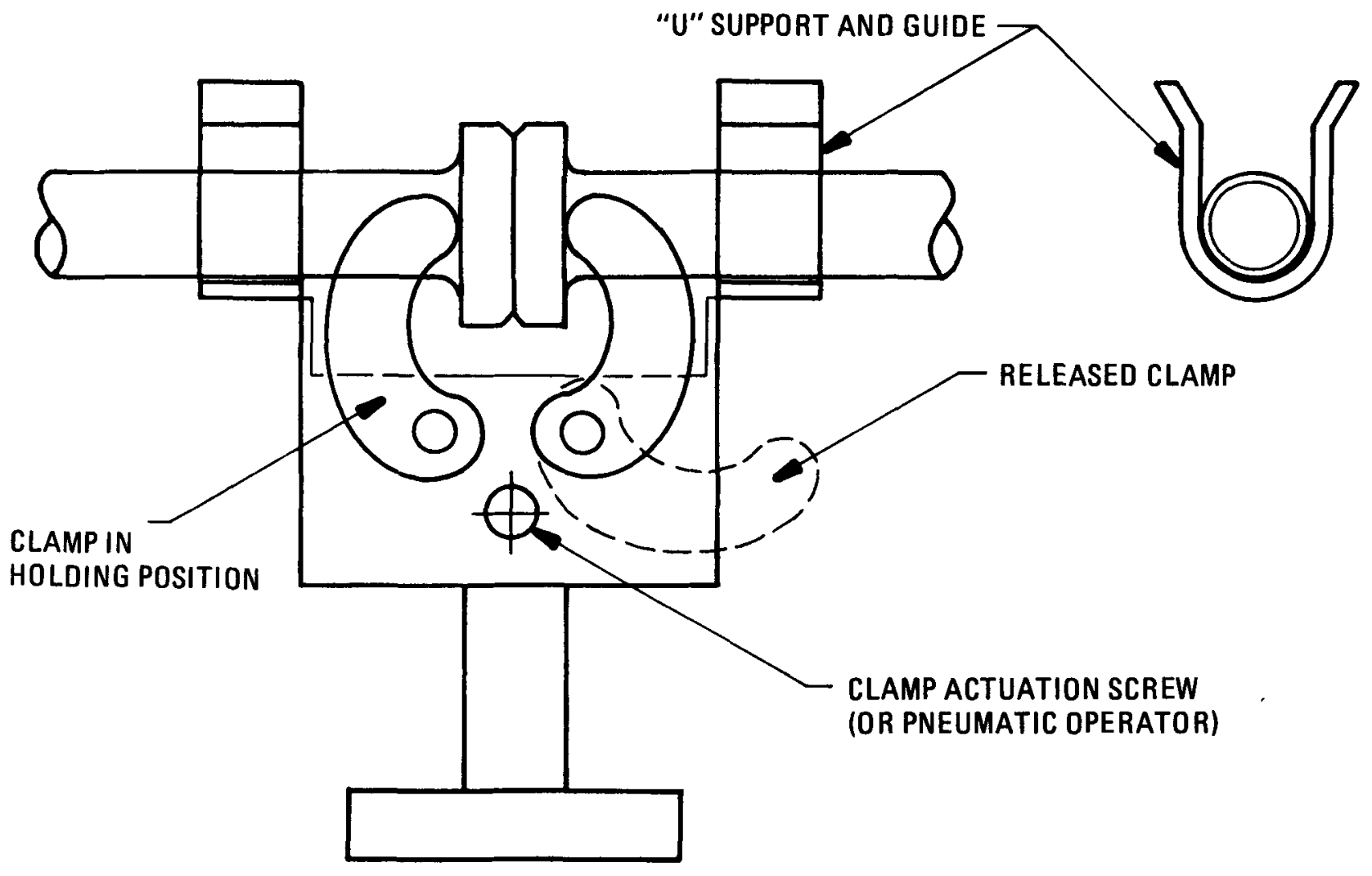

Fig. 1. Integral pipe coupling and pipe support 
2. Bellows Coupling (Fig. 2). This type of coupling also serves to relieve the stresses caused by thermal expansion of the transport lines. An airtight seal may be difficult to maintain in areas of high-temperature service because of the types of seals available.

3. Commercially Available Couplings. Commercial couplings may be available which with little or no modification will perform the required functions.

3.1.2.5. Discussion and Recommendations. Since at the present time a remote coupling design has not been determined, it is recommended that a test program be established to define the couplings required in the HRRF.

3.1.3. Methods of Detecting the Occurrence and Location of Flow Blockages in the Conveying Lines

3.1.3.1. Function. Methods are required to detect and locate a blockage in a conveying line. The location of the blockage must be determined so that the blockage can be removed and flow reestablished.

3.1.3.2. Design Requirements. Methods of detecting and locating blockages should employ equipment which is simple, radiation resistant, easily operated remotely, and easily maintained.

3.1.3.3. Operating Experience. The method now used in the cold engineering pilot plant to detect the occurrence of a blockage is the abrupt increase in system differential pressure. The blockages are located by tapping on the transport line and evaluating the acoustic response. 


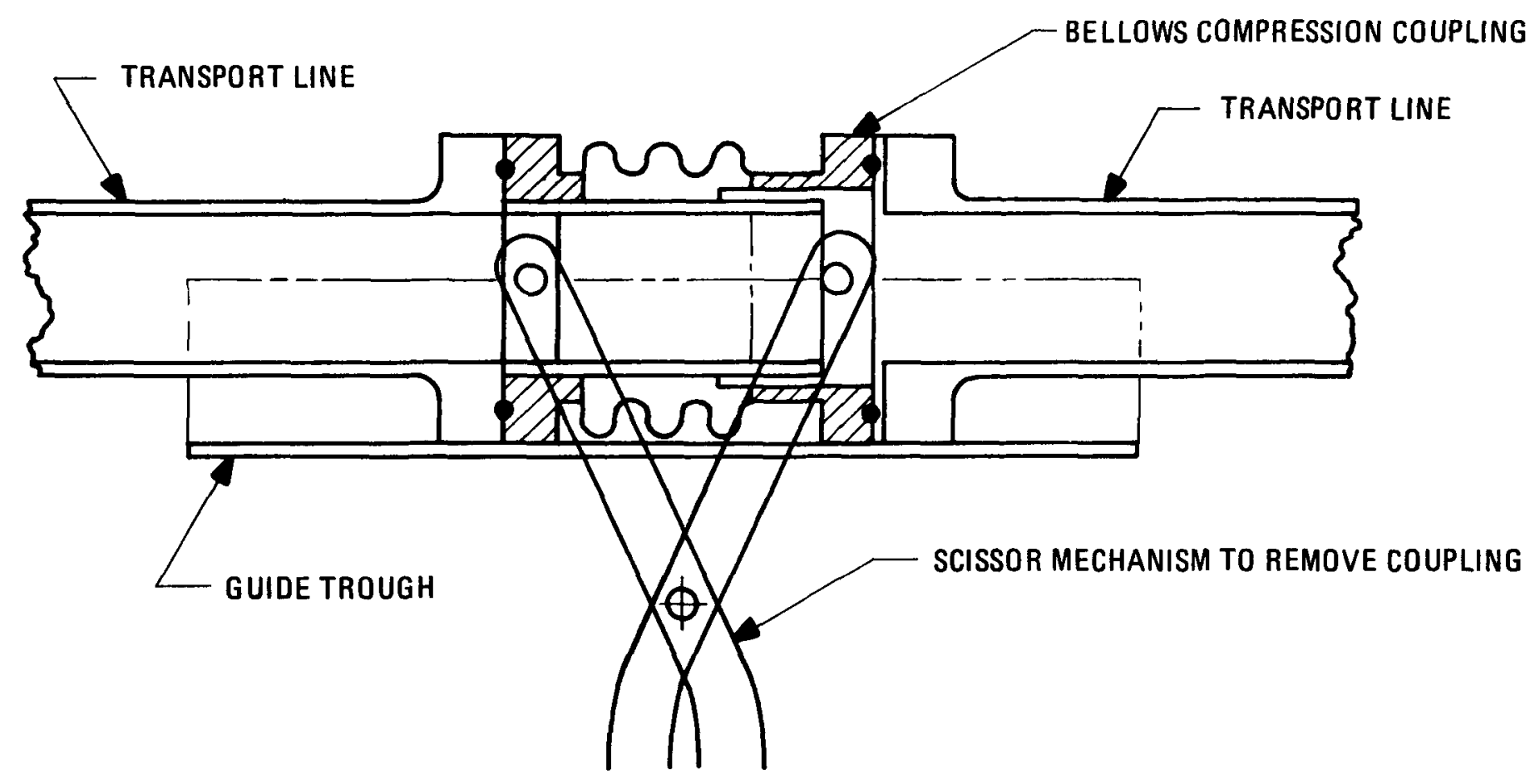

Fig. 2. Bellows coupling 


\subsubsection{Alternatives}

\section{Detection}

1. Differential Pressure Monitoring. The method present1y used, observation of the abrupt increase in system pressure drop, has the advantage of a rapid response time, and it requires only simple instrumentation. The disadvantage is that the system pressure drop also varies with other system parameters (e.g., mass transport rate, filter loading, etc.).

2. Loss of Feed to Storage Bunker. This method of detection has an inherently slow response time because it relies on detecting the absence of a weight increase in the storage bunker.

3. Loss of Flow Indication by a Flow Sensor. This method has a very rapid response to a flow blockage. It also indicates a loss of feed to the system. A reliable flow rate sensor, however, has not yet been developed.

\section{Location}

1. Sonic Plug Detector (Fig. 3). This unit has the advantage of being independent of the transport system; in addition, one detector serves the entire system. The unit can be completely self-contained and removable from the cell for repair. However, significant development is needed to evolve a unit that is reliable, radiation resistant, and remotely operable.

2. Acoustic P1ug Detector (Fig. 4). This unit is relatively simple, provides direct readout of the plug location, and requires no in-cell (remote) operations. However, this method involves significant development costs. 


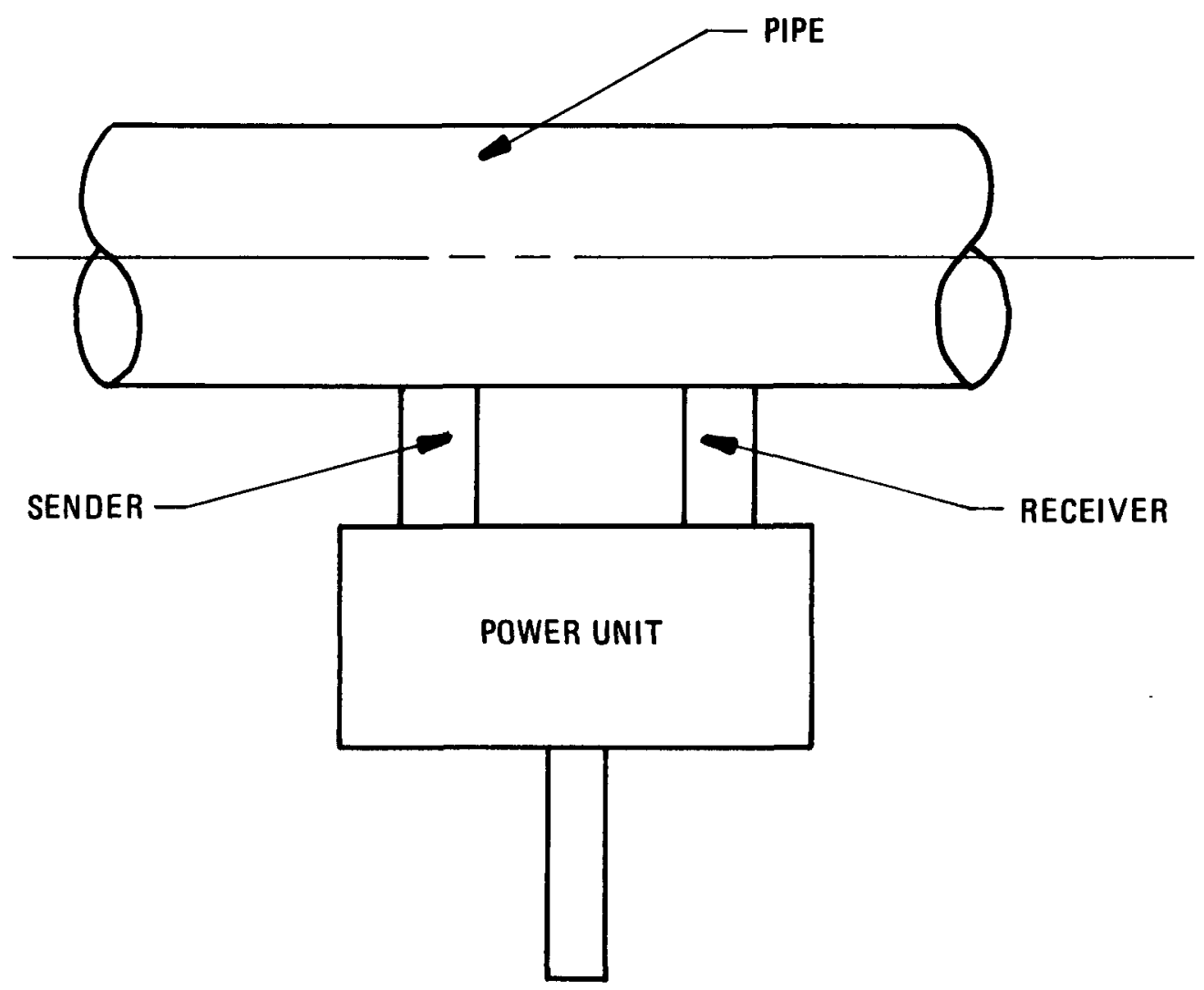

Fig. 3. Sonic plug detector 
ACOUSTIC

TRANSDUCER

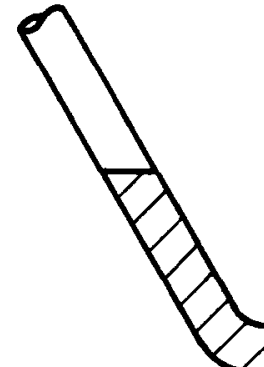

PLUG

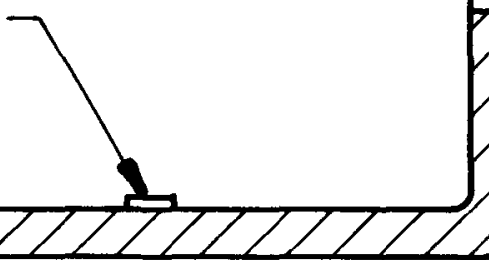

UNPLUGGED LENGTH (1) CAN BE ESTAB LISHED

BY LOWEST COLUMN RESONANT FREQUENCY,

i.e., FREQUENCY AT WHICH TRANSDUCER

RESISTANCE IS A MAXIMUM.

Fig. 4. Acoustic plug detector 
3. Sound. This method is essentially the same as is now used in the cold engineering pilot plant. The only change is the installation of a microphone in the cell to allow the operator to hear the sound when the conveying line is tapped. This method has distinct advantages in that it is very simple and requires essentially no development. The disadvantage is that it requires that a11 points in the conveying system be accessible to a tapping mechanism.

4. Detecting High Radiation at the Plug. This method has the advantage of being separate and independent of the transport system. The technology required has already been developed. Its disadvantage is that nearby storage bunkers or the background radiation may make the information obtained from this method difficult to interpret, and a shielded detector would be difficult to position in a hot cell environment.

5. Pressure Monitoring at Intervals Along the Conveying Line. The advantages of this method are that the information is readily interpreted and the technology presently available. These connections could also be used for gas injection (see Section 4.1.4.4, "High Pressure Gas Injections"). The disadvantage is that it requires numerous physical connections to the transport line, which complicates remote maintenance.

3.1.3.5. Discussion and Recommendations. Of the methods of detection discussed, the differential pressure monitoring and the flow sensors are the most workable. The loss of feed to the storage bunker method is slow in responding and allows considerable material to be fed into the plugged line, thus amplifying the problem of plug removal. The best alternative is a combination of flow rate sensors and system differential pressure so that high differential pressure and absence of flow indicate a blockage. It is recommended that development of a reliable flow rate sensor be reemphasized and included in future program plans. 
The method used to detect blockage location in the cold engineering pilot plant (sound) appears to be feasible for use in a hot cell. However, it is recommended that further studies be made before a method is chosen for the HRRF.

\subsubsection{Methods of Removing Flow Blockages}

3.1.4.1. Function. A method and equipment must be developed to allow remote unplugging of transport lines so that normal operations can resume.

3.1.4.2. Design Requirements. The method of removing flow blockages should be simple and reliable, and it should require a minimum of in-cell equipment. Attachments to the transport piping must be kept to a minimum to reduce other in-cell maintenance problems.

3.1.4.3. Operating Experience. Present operating experience has been limited to restarting flow by either increasing system differential pressure, tapping on the blocked line segment to redistribute the material and then increasing system differential pressure, or disassembling and either rodding or dumping out the plugged portion of the line. In one case, flow was restarted by admitting air to the area of the blockage and removing the plug by conveying a portion of it at a time.

\subsubsection{Alternatives}

1. Gas Inlet Valves (Fig. 5). There are two alternatives in this method of removing flow blockages. If the cell atmosphere is the same as that of the motive gas, the valves can be opened to the cell and gas drawn in; otherwise, a gas supply to each valve is needed. The latter is a major disadvantage during cell maintenance. The main advantage of the in-1ine valve is that no in-cell support equipment is needed to operate the system. 

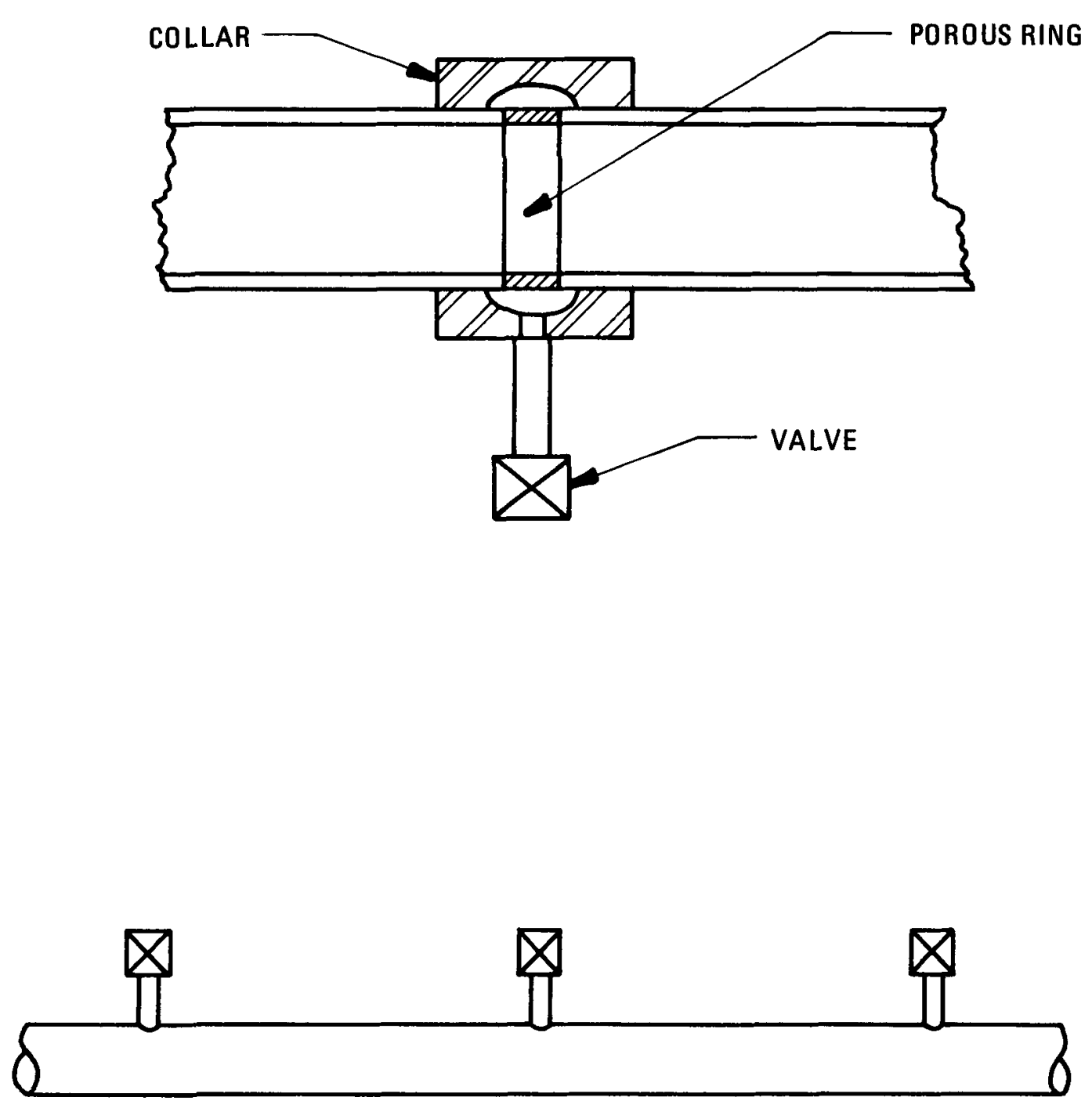

Fig. 5. In-1ine valve 
2. Cleanout Ports in the Line (Fig. 6). In this method, cleanout ports are located at strategic points throughout the transport system. If a blockage occurs, the ports in the blockage area are opened and the contents of the conveying line are removed with a suction device. The contents can be drawn to a holding container, or the suction line can be tied directly to the necessary bunker; in the second case the cell atmosphere and motive gas must be the same. This system has the disadvantage that the cleanout ports must be remotely accessible.

3. High-Pressure Gas Injections. This method utilizes high-pressure gas injected into the system either at the inlet or at the area of the blockage. It requires external connections to the conveying lines. The chief disadvantage is that provisions must be made to either protect some of the equipment or design it to withstand these gas pressures.

4. Vibrators. Vibrators can be attached to the transport in areas where blockages are expected to occur. The use of vibrators to unplug transport 1 ines requires verification; they may tend to pack rather than remove the material causing the blockage.

5. Disassembly. The method that is the most effective but also the most difficult to accomplish in a hot cell environment is to disassemble and either empty or rod out the blocked portion of the line. With this method, spillage and cleanup require appropriate consideration.

3.1.4.5. Discussion and Recommendations. Methods of removing flow blockage have not been thoroughly studied, and no recommendations as to the best method can be made. Consequently, it is recommended that further studies, including a survey of present industry practices, be made in this area. Based on present knowledge, provistons should be made for line disassembly as a last resort for removing a particularly stubborn blockage. 

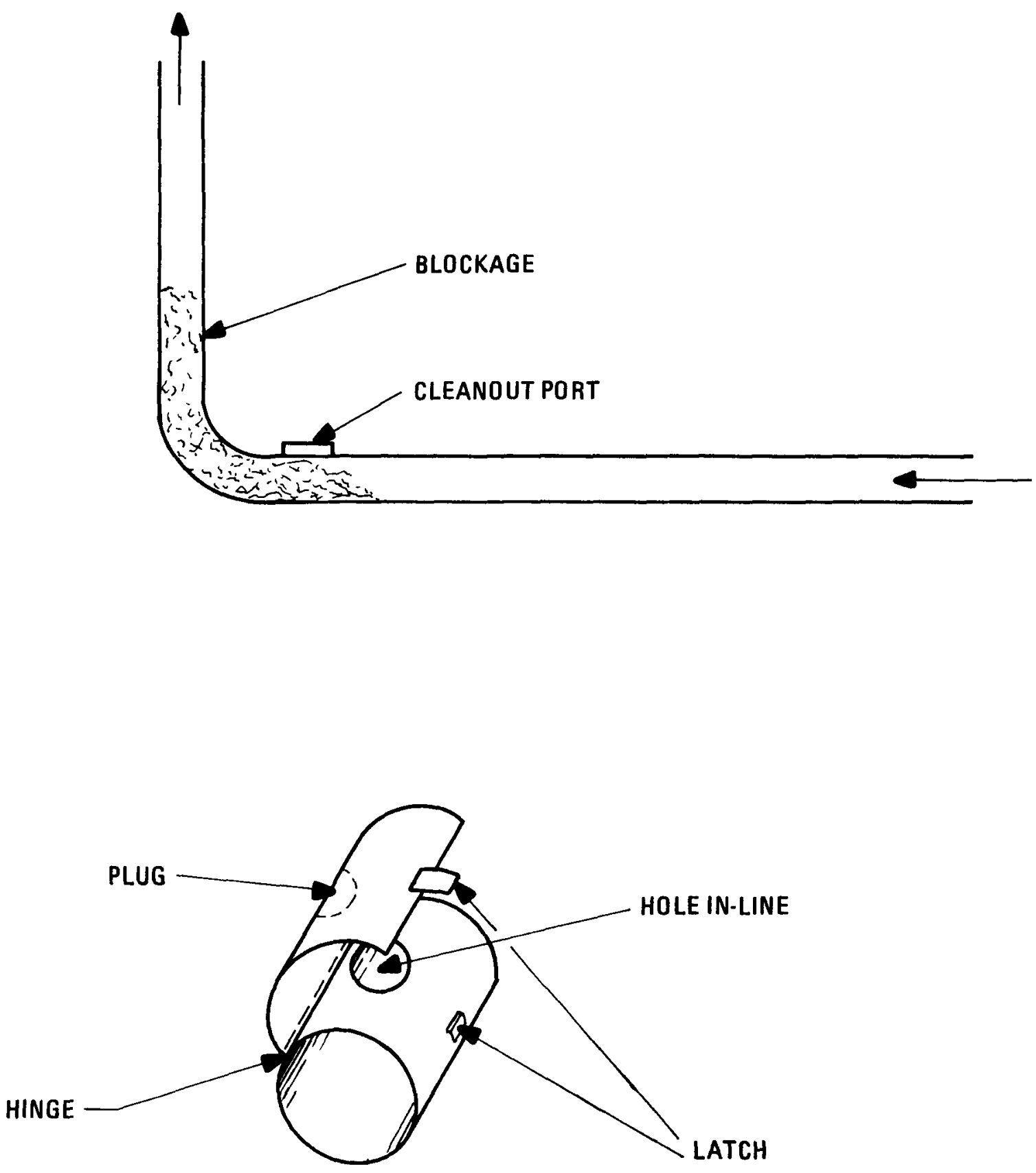

CLEANOUT PORT DETAIL

Fig. 6. Cleanout port 


\subsubsection{Method of Detection and Prevention of Bend Erosion}

3.1.5.1. Function. It is known that transporting abrasive material through pneumatic transport lines causes erosion of the transport piping, with the majority of the wear occurring at the bends. Methods must be developed to prevent this erosion from causing leaks and therefore the shutdown of the conveying system.

3.1.5.2. Design Requirements. The method chosen should be reliable and easy to implement in-cell.

3.1.5.3. Operating Experience. At present, with the very low operating times compared to those expected in the HRRF, there is no detectable transport piping wear in the cold engineering plant. Attempts made to measure the rate of wear in the piping bends using an ultrasonic device have been unsuccessful so far (Ref. 3).

\subsubsection{A1ternatives}

1. Manufacture of Bends from Hardened Materials. Depending on the wear rates, this method either reduces or eliminates maintenance over the plant life.

2. Manufacture of Bends from Thicker Materials. This has the same effect as hardening the walls.

3. Attachment of Backup Plates to the Wear Areas of Bends. This has the same effect as thickening the walls.

4. In-Service Inspection to Determine Wear Areas. This requires the development of remote methods of measuring pipe wall th1ckness. 
5. Periodic Replacement of Parts Subjected to Wear. This proposa1 essentially involves establishing wear rates and replacing parts before they wear through.

3.1.5.5. Discussion and Recommendations. Since it is unknown at present whether wear rates will present an operational problem, it is recommended that wear rates for various systems be established experimentally. Since the design of the conveying lines will include provisions for easy disassembly, the most viable solution to possible wear problems is periodic replacement of parts based on predicted wear.

\section{2. IN-BUNKER FILTERS}

\subsubsection{Introduction}

One design feature of the in-bunker filters was identified as requiring further evaluation, i.e., the configuration of the filter blowback piping.' These filters are used to separate the motive gas from the solids in the storage bunkers.

\subsubsection{Filter Blowback Configuration}

3.2.2.1. Function. The filter blowback is used to prevent the loading of fines on the sintered metal filters from causing a large system differential pressure and also to prevent a holdup of material which could compromise accountability.

3.2.2.2. Design Requirements. The filter blowback system is required to remove fines which bulld up on the sintered metal filters.

3.2.2.3. Operating Experience. The present design functions adequately; however, the precise alignment required between the gas jets and the venturis causes fabrication to be very difficult. No investigation has been made into the acceptable tolerances for alignment; instead, the manufacturer's recommendations have been used. 


\subsubsection{Alternatives}

1. Study and Increase of Tolerances if Possible. This method requires an extensive experimental program. The only advantage would be an increase in tolerances if the study indicated that this is possible.

2. Change of Design and Assemb1y Method (Fig. 7). The proposed assembly method allows close alignment of the gas jet and venturi with much less difficulty than the method presently used, and disassembly for maintenance is simple.

3.2.2.5. Discussion and Recommendations. Since the manufacturer has recommended the tolerances that are now in use, it is unlikely that an experimental program to determine the required tolerances will yield a significant relaxation. The alternative method of construction offers several advantages and no apparent disadvantages and is, therefore, recommended.

\subsection{LEVEL SENSORS}

\subsubsection{Introduction}

The need for reliable level sensors in all of the storage and feed bunkers was identified. These level sensors are needed as a backup to bunker weighing by load cells to prevent overfilling.

\subsubsection{Level Sensor Requirements}

3.3.2.1. Function. The level sensors must detect a high-level condition in any of the bunkers. This is required in addition to the weighing system because the density of the material being stored in the bunker can vary substantially during off-standard conditions. 


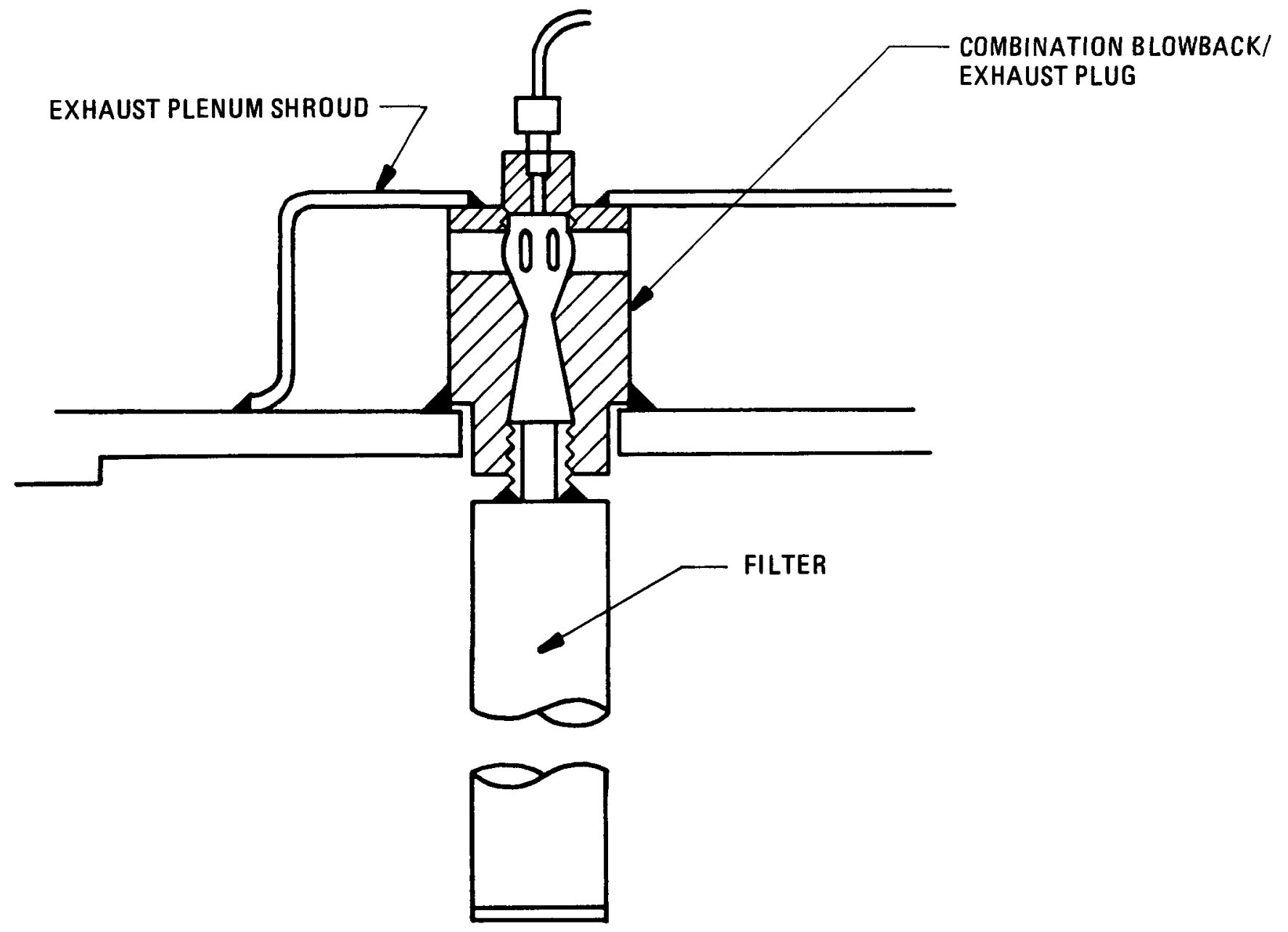

Fig. 7. Alternate assembly method for filter blowback 
3.3.2.2. Design Requirements. The level sensors must function reliably with all of the possible materials that can be stored in the bunkers, including those under abnormal conditions. The level sensors must function in a high radiation environment and, in the case of the burner product bunkers, high temperatures.

3.3.2.3. Operating Experience. U1trasonic level detectors, which work on the principle of the material interrupting an ultrasonic beam, have been used in the cold engineering pilot plant. Difficulty has been experienced with these under dusty conditions. A layer of dust on the transducer gives a high level indication. Resistance detectors have been used in areas other than the transport system with some success.

\subsubsection{Alternatives}

1. U1trasonic Detectors. The present ultrasonic detectors require some development to make the electronics radiation resistant. A gas jet impinging on the transducer surface may eliminate the problem of a dust coating that is giving a false reading. An ultrasonic detector will work with all types of materials.

2. Vibrating Reed Detectors. The vibrating reed sensors should work with all types of materials. These sensors should be selfcleaning so that a dusty atmosphere should cause no problems. They have the disadvantage of requiring that radiation-resistant hardware be developed.

3. Resistance Detectors. Resistance detectors have proved reliable in the areas where tested in the cold engineering pilot plant. These may have a problem in high dust areas where the material being stored is electrically conductive.

4. Capacitive Detectors. There is no experience in-house with capacitive level sensors. Radiation-resistant hardware has to 
be developed. Capacitive level sensors work only when the material being stored is dielectric. Burned-back particles are dielectrics, but burner feed is not.

3.3.2.5. Discussion and Recommendations. The selection of a level detection system requires further development. The selection of one type of level sensing system for all areas is advantageous because of maintenance considerations. In addition, a level sensing system that can function with all materials would be operable in any upset condition. It is recommended that the level sensor development program be continued, with emphasis on systems that are universal in the plant.

\subsection{FEEDERS}

\subsubsection{Introduction}

Three areas of the pneumatic transport system were selected as requiring further investigation regarding the need of a feeder and the type of feeder required. These areas are:

1. Crusher discharge.

2. Secondary burner product bunker to transport system.

3. Primary burner feed.

\subsubsection{Crusher Discharge}

3.4.2.1. Function. The discharge from the crusher (UNIFRAME) should be regulated to prevent both lean conditions, which cause high transport velocities, and heavy feed condtions, which cause flow blockage.

3.4.2.2. Design Requirements. The feeder must deliver a steady feed rate to the transport system. This will allow a lower transport velocity, which reduces fuel particle breakage. If an oversize monitoring system is included in the final crusher design, it must feed from both the UNIFRAME and the oversize monitoring system. 
3.4.2.3. Operating Experience. At present, no feed regulation is used on the crusher discharge. Therefore, the gas velocity must be maintained at a high rate to handle the heaviest feed condition. This causes high transport velocities and, consequently, higher than acceptable particle breakage in a11 except the heavy feed conditions.

3.4.2.4. Discussion and Recommendations. A rotary feed valve will be installed on the UNIFRAME discharge. The screener and the oversize crusher products will be fed through a common valve. It is recommended that the effects of particle breakage incurred in transport from the crusher be monitored after the installation of the rotary feed valve to determine if the single valve is satisfactory.

\subsubsection{Secondary Burner Product Bunker to Transport System}

3.4.3.1. Function. The secondary burner product is a very fine, dense, cohesive material. This material must be removed from the secondary product bunker and transported to the dissolver feed bunkers. A feeder is required to regulate flow to the transport line.

3.4.3.2. Design Requirements. The feed system must be capable of removing the secondary burner product from the bunker without bridging and yet be able to regulate the flow to prevent flooding.

3.4.3.3. Operating Experience. The only experience in handling the secondary burner product has been in emptying the secondary burner. This experience has shown that in the fluidized state this material flows very easily.

\subsubsection{Alternatives}

1. Rotary Valve and Aerated Bottom. This method has the advantages of positive feed and an easily controlled feed rate with this fine, cohesive material. The material may fluidize with aeration 
but will not flood. A rotary valve has the disadvantage of having moving parts in an abrasive environment; therefore, it is subject to wear and failure.

2. Auger and Aerated Bottom. This method has positive feed and will not easily flood. In addition to having moving parts in an abrasive environment, it has the disadvantage that augers do not empty completely, which has material accountability implications.

3. Variable Position Valve and Aerated Bottom. This method does not give positive feed and may flood if the opening is kept large enough to prevent bridging. This method also requires moving parts in a very abrasive environment.

4. Fixed Orifice and Aerated Bottom. This method has an advantage in that it has no moving parts in the abrasive environment. However, an orifice large enough to prevent bridging is probably too large to prevent flooding.

3.4.3.5. Discussion and Recommendations. Even though moving parts in-cell in this abrasive environment are a distinct disadvantage, they appear necessary to prevent flooding and subsequent blockage of the transport line. Of the alternatives, the rotary feed valve appears to have the least number of disadvantages. It is recommended, therefore, that a rotary feed valve be tested on the secondary burner product bunker in the cold engineering plant.

\subsubsection{Primary Burner Feeder}

3.4.4.1. Function. The primary burner feeder introduces fresh feed into the primary burner continuously during a run. The feeder also prevents the high-temperature gas in the burner from escaping into the feed bunker. 
3.4.4.2. Design Requirements. The feeder must furnish continuous feed to the primary burner. It should be large enough to prevent bridging in the feed bunker. It should also prevent hot burner gas from flowing back into the feed bunker.

3.4.4.3. Operating Experience. Present operation utilizes a rotary feed valve. This valve is not large enough and consequently the feed hopper has bridged several times. Also, the single feed hopper requires that burner feed be stopped while it is being recharged.

3.4.4.4. Discussion and Recommendations. The 4-in. rotary feed valve on the crusher product bunker has never bridged. It is recommended that this size rotary valve be installed on the primary burner feed bunker. To permit refilling of the bunker while feed to the burner is maintained, a surge hopper should be considered.

\subsection{WEIGH CELLS}

\subsubsection{Introduction}

Two design areas in the weigh cell system were identified as requiring further evaluation: (1) the needed design of a system for use in a hot cell, and (2) the structural considerations involved with supporting the bunkers on the load cells while eliminating the transfer of force from perfpheral equipment to the load cells. The design of the system for incell use involves developing radiation-resistant equipment that can be operated and maintained remotely. This will be done under future activity plans and is not covered in this report. Two of the structural considerations, support and connection to the bunkers, are addressed in general terms. Specific designs will be evaluated when criticality and heat transfer considerations allow the bunker size and shape to be defined. 


\subsubsection{Bunker Support Structure}

3.5.2.1. Function. The bunker support structure supports the bunker and peripheral equipment. It transfers the weight of the bunker to the load cells.

3.5.2.2. Design Requirement. The support structure must be designed in such a manner that only vertical forces are transferred to the load cells. Rotational and horizontal forces must be eliminated. The support structure must be rigid so as to minimize the transfer of vibrations to the weigh system.

3.5.2.3. Operating Experience. Weigh cells are now installed on the storage bunkers in the cold engineering pilot plant. Two of these, the crusher product and primary burner product bunkers, have redesigned rigid support structures. The bunkers are supported on three weigh cells in a triangular arrangement. Tie bars are installed to prevent rotation of the bunkers but allow a limited amount of vertical movement. The weigh systems on these bunkers give satisfactory results. Problems were experienced in the crusher product bunker when it was loaded to capacity; a reversible failure in the weigh cells occurred because the tie bars to prevent rotation were not aligned correctly.

3.5.2.4. Discussion and Recommendations. The present rigid support system appears to be acceptable, but further work should be done on this system to assure proper alignment of the tie bars.

\subsubsection{Bunker Connections}

3.5.3.1. Function. The bunker must be connected to the transport system by a method that prevents transfer of vertical force from the bunker to the transport piping. This allows the weigh cells to give an accurate measurement of the bunker contents. 
3.5.3.2. Design Requirements. These connections must be leak-tight, provide no spaces for material holdup, be flexible enough to prevent the transfer of weight, and be radiation resistant.

3.5.3.3. Operating Experience. Metal bellows with a liner tube are presently used in the cold engineering pilot plant to connect the bunkers to the transport system. With this configuration, material is trapped between the liner tube and the bellows. This has material accountability implications.

\subsubsection{Alternatives}

1. Unlined Bellows. This method prevents material from being trapped between the liner and the bellows, but the thin bellows can wear rapidly from material striking the convolutions, and material can still be trapped in the convolutions.

2. Sliding Seals. These seals present a smooth surface to the materials being transported. A development effort is required to assure that the seals are leak-tight and sufficiently low in friction.

3.5.3.5. Discussion and Recommendations. Development work is still needed in this area. It is very important to have connections that are non-loadtransferring and leak-tight. It is recommended that further investigations be made on the two proposed systems or combinations of both systems.

\subsection{SAMPLERS}

Five different types of samplers have been tested and evaluated in the cold engineering pilot plant. The results of these tests are reported in Ref. 4. 
Two areas concerning the sampling program have been identified as needing further definition:

1. The process streams to be sampled.

2. The required accuracy of samples in relation to the sampled stream composition.

One major point relating to both areas which requires definition is whether the samples are to be used only for process information or also for material accountability. Less accuracy is required if they are to be used only for process information. Also, the sample retrieval and analysis time must be much shorter for process information than for accountability purposes. The requirements of the sampling system must be defined prior to further development of a sampling plan.

\subsection{PNEUMATIC CLASSIFIER}

\subsubsection{Introduction}

The pneumatic classifler is a zig-zag column where fuel particles are fed into a moving gas stream. The 1ighter, small particles, predominately fissile, are entrained in the upward flowing gas, are separated from the gas by a cyclone and filter, and fall into a receiving bunker. The heavier, large particles, predominately fertile, fall through the gas stream into a separate receiving bunker. A more complete description of the classification system can be found in Ref. 5 .

Three areas of design on the air classifier were identified as requiring further evaluation. These are:

1. Combining the cyclone separator, filter, and possibly the fissile bunker for the classifier overflow into a single unit. 
2. Reducing the thorium crossover to the overflow by shapeseparating after classification.

3. Reducing the uranium crossover to the underflow by differential leaching of the uranium fines from the thorium kernels.

3.7.2. Combination of the Cyclone, Filter, and Possibly the Fissile Bunkers

3.7.2.1. Function. This equipment separates the solids from the classifier overflow from the gas stream and stores the solids for further processing.

3.7.2.2. Design Requirements. The solids must be efficiently separated from the gas stream without filter blocking and without fine particles escaping to the gaseous effluent system.

3.7.2.3. Operating Experience. At present in the cold engineering pilot plant, the cyclone, filter, and storage bunker are separate units (Fig. 8). Operating experience has demonstrated that the present cyclone is inefficient and allows a significant quantity of whole fissile particles to end up in the filter chamber (Ref. 6). The filter chamber contents must then be recombined with the fissile bunker contents prior to subsequent operations, in order to recover these fissile particles.

\subsubsection{Alternatives}

1. Combination of Cyclone and Filter (Fig. 9). This method eliminates one piece of equipment and reduces associated maintenance problems. The disadvantages are that the cyclone outlet and the fissile bunker need to be designed to handle the filter fines, and the fines cannot be separated from the fissile particles.

2. Combination of Cyclone, Filter, and Bunker (Fig. 10). This arrangement simplifies the equipment requirements even more. It 


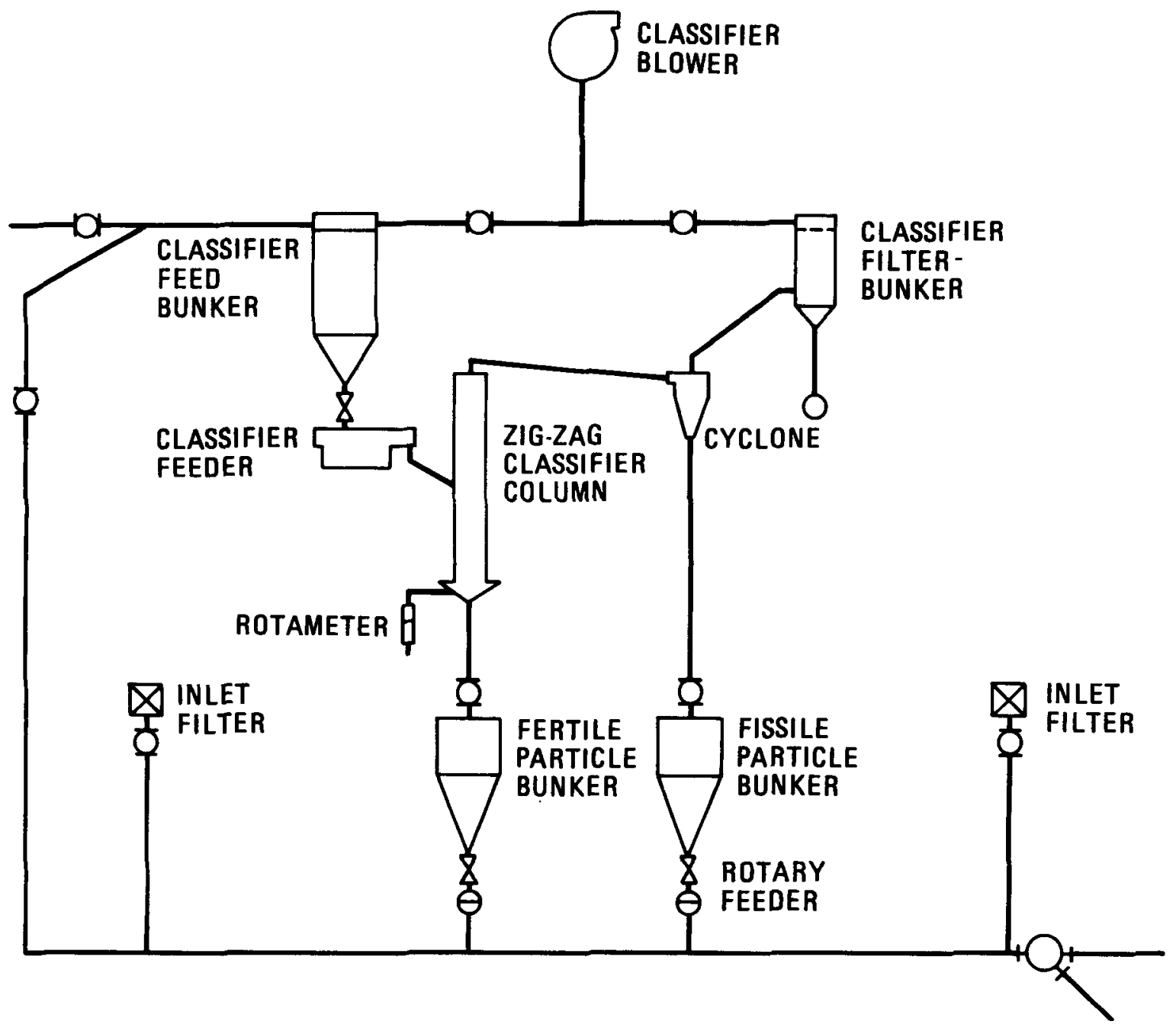

Fig. 8. Schematic diagram of fuel particle classifier 


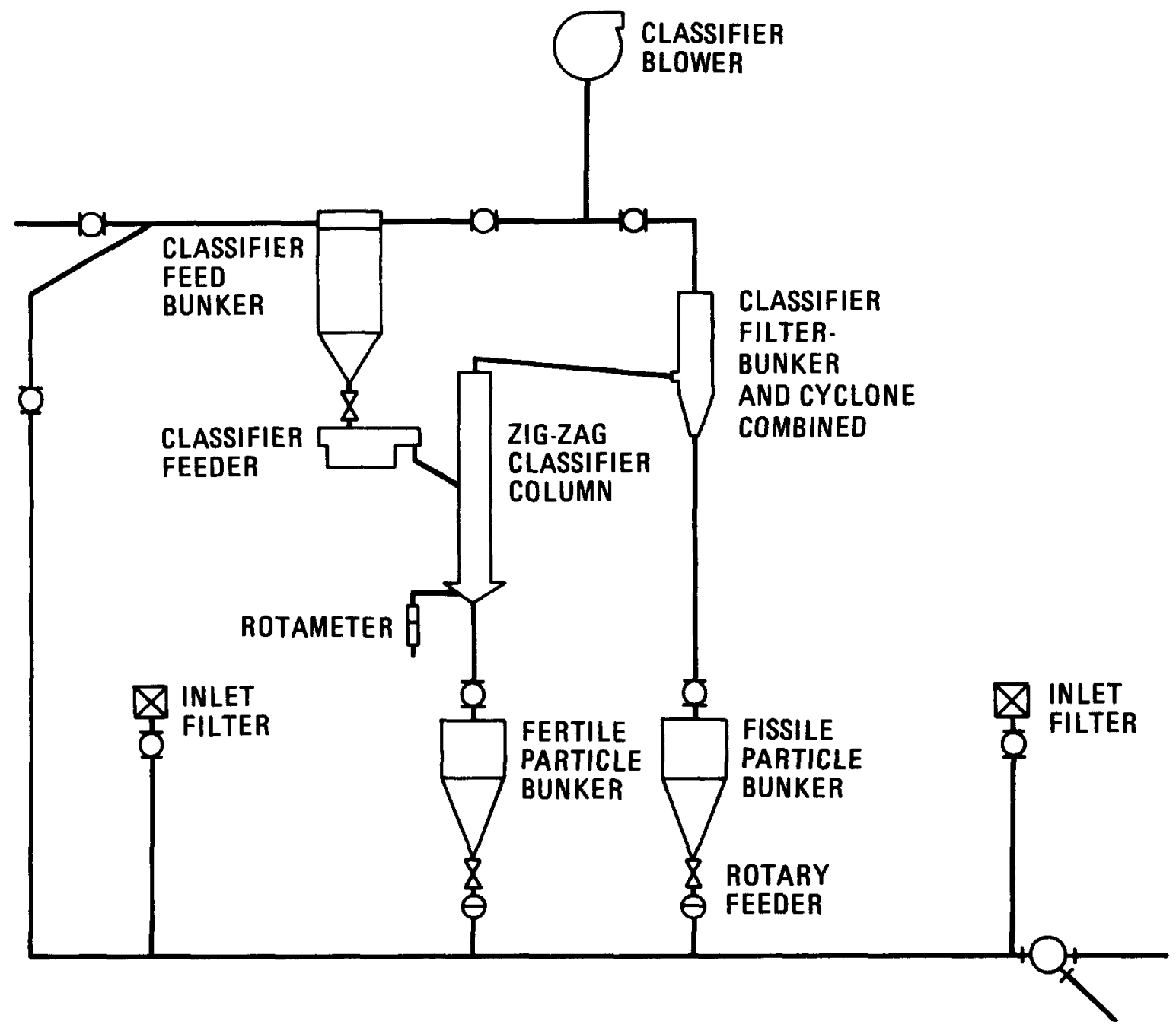

Fig. 9. Schematic diagram of fuel particle classifier with cyclone and filter combined 


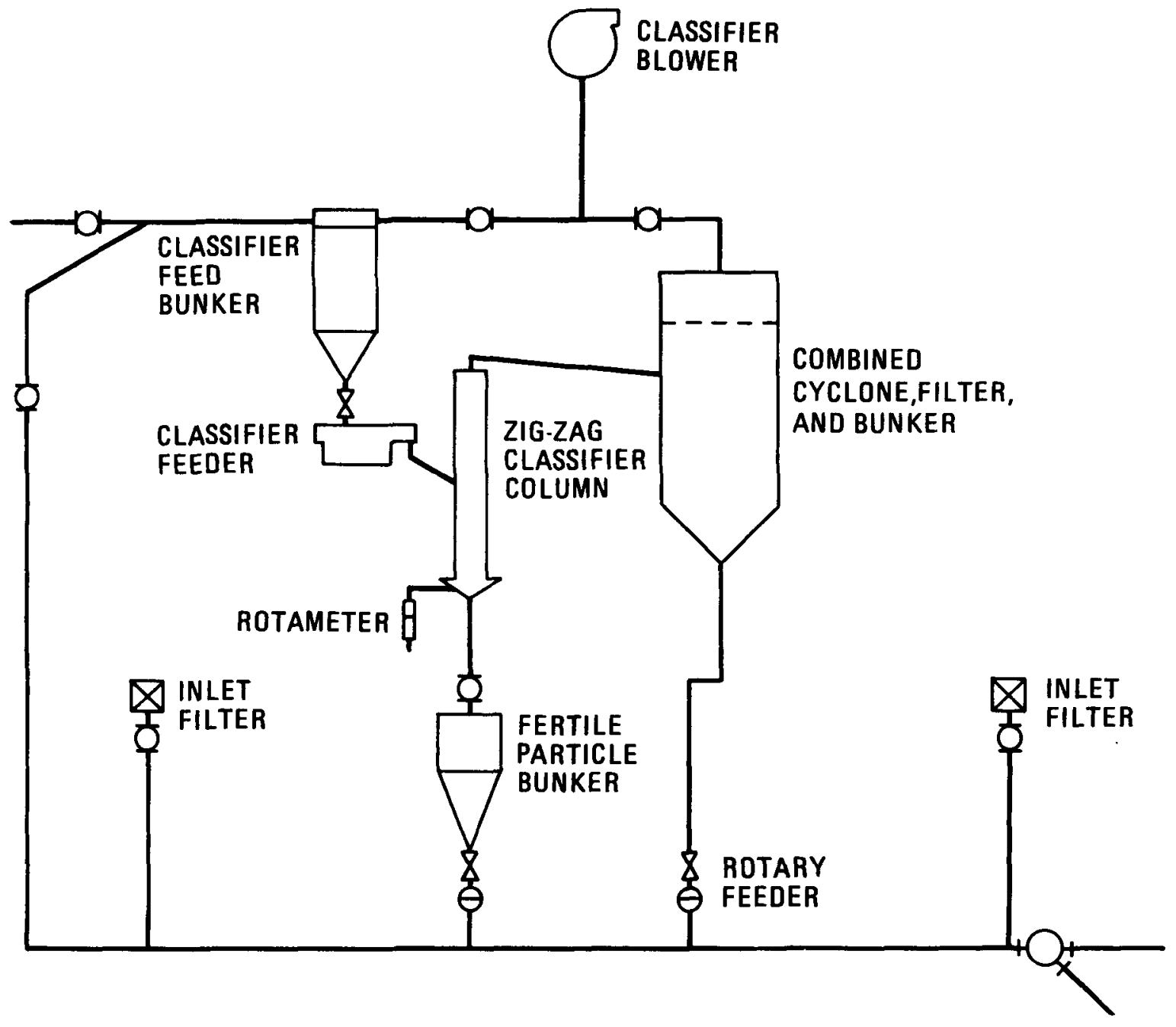

Fig. 10. Schematic diagram of fuel particle classifier with cyclone, filter, and bunker combined 
has the same disadvantages as combining the cyclone and filter and, in addition, imposes problems in sampling the overflow stream early enough to permit recycle back to the classifier without significant flowsheet changes.

3.7.2.5. Discussion and Recommendations. The major disadvantage of both of these systems is that the fines are not separated from the fissile particles. This need has not yet been identified and must be resolved prior to making any decisions regarding combining the cyclone and filter. If the cyclone and filter can be combined, it appears that the fissile storage bunker should be kept separate to simplify sampling and recycle considerations.

\subsubsection{Shape Separation of Classifier Overflow}

Operating experience in the cold engineering pilot plant has demonstrated that the majority of the fertile particle crossover to the classifier overflow is caused by broken fertile particles being carried overhead. A shape separator separates the whole particles from the fragments. This gives two fractions, whole fissile particles and broken fertile and fissile particles. Fissile material in the broken particles must then be separated from the fertile particle fragments, possibly by differential leaching. This method of separation should be investigated further in future experimental work.

\subsubsection{Differential Leaching of Classifier Underflow}

Operating experience in the cold engineering pilot plant has shown that some uranium crossover to the classifier underflow may be caused by broken TRISO $\left(\mathrm{UC}_{2}\right)$ particles in which the $\mathrm{UC}_{2}$ has been oxidized into a fine $\mathrm{U}_{3} \mathrm{O}_{8}$ powder. This powder adheres to the $\mathrm{BISO}\left(\mathrm{ThO}_{2}\right)$ kernels and is carried into the classifier underflow. Differential leaching has been suggested as a possible method to separate the fine powder from the $\mathrm{ThO}_{2}$ kernels. This method warrants further study and should be included in future experimental investigations. 


\section{ACKNOWLEDGMENTS}

The author would like to acknowledge the help of the following contributors in preparing this design evaluation: E. J. Cook, R. D. Crabtree, R. E. Field, N. W. Johanson, P. C. Richards, and W. S. Rickman. 


\section{REFERENCES}

1. "The General Atomic Reprocessing Pilot Plant: Description and Results of Initial Testing," DOE Report GA-A-14642, General Atomic Company, December 1977.

2. Cook, E. J., and J. M. McNair, "Solids Transport System for HTGR Fuel Reprocessing: Interim Development Report," DOE Report GA-A14958, General Atomic Company, to be published.

3. Cook, E. J., General Atomic Company, private communication, December 1977.

4. Cook, E. J., and P. C. Richards, "Selection and Testing of On-Line Samplers for Head-End Reprocessing," DOE Report GA-A14634, General Atomic Company, October 1977.

5. Strand, J. B., "Particle Classifier for HTGR Fuel Reprocessing," DOE Report GA-A14930, Genera1 Atomic Company, Ju1y 1978.

6. Strand, J. B., General Atomic Company, private communication, December 1977. 


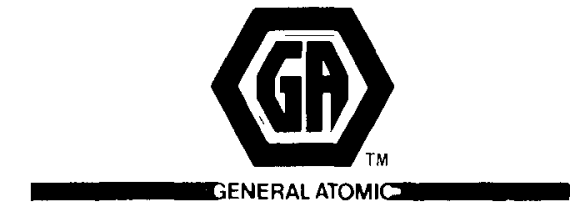

GENERAL ATOMIC COMPANY

P. O. BOX 81608

SAN DIEGO, CALIFORNIA 92138 